\title{
Physical, Anatomical, and Biochemical Composition of Skins Cell Walls from Two Grapevine Cultivars (Vitis vinifera) of Champagne Region Related to Their Susceptibility to Botrytis cinerea during Ripening
}

\author{
Marie André 1,2,*(D), Soizic Lacampagne ${ }^{1}$, Audrey Barsacq ${ }^{1}$, Etienne Gontier ${ }^{3}$, Melina Petrel ${ }^{3}$, Laurence Mercier ${ }^{2}$, \\ Diane Courot $^{2}$ and Laurence Gény-Denis ${ }^{1}$ \\ 1 Unité de Recherche Enologie, EA 4577, USC 1366 INRAE, ISVV, Bordeaux Université, \\ 33882 Villenave d'Ornon, France; soizic.lacampagne@u-bordeaux.fr (S.L.); \\ audrey.barsacq@u-bordeaux.fr (A.B.); laurence.geny-denis@u-bordeaux.fr (L.G.-D.) \\ 2 MHCS, Laboratoire de Recherche \& Développement, 9 Avenue de Champagne, 51200 Epernay, France; \\ lmercier@moethennessy.com (L.M.); dcourot@moethennessy.com (D.C.) \\ 3 Bordeaux Imaging Center (BIC), Bordeaux University, UMS 3420, CNRS, INSERM, US 4, 33000 Bordeaux, \\ France; etienne.gontier@u-bordeaux.fr (E.G.); melina.petrel@u-bordeaux.fr (M.P.) \\ * Correspondence: marie.andre@u-bordeaux.fr
}

check for updates

Citation: André, M.; Lacampagne, S.; Barsacq, A.; Gontier, E.; Petrel, M.; Mercier, L.; Courot, D.; Gény-Denis, L. Physical, Anatomical, and Biochemical Composition of Skins Cell Walls from Two Grapevine Cultivars (Vitis vinifera) of Champagne Region Related to Their Susceptibility to Botrytis cinerea during Ripening. Horticulturae 2021, 7, 413. https://doi.org/10.3390/ horticulturae7100413

Academic Editor: Massimo Bertamin

Received: 30 September 2021

Accepted: 13 October 2021

Published: 18 October 2021

Publisher's Note: MDPI stays neutral with regard to jurisdictional claims in published maps and institutional affiliations.

Copyright: () 2021 by the authors. Licensee MDPI, Basel, Switzerland. This article is an open access article distributed under the terms and conditions of the Creative Commons Attribution (CC BY) license (https:// creativecommons.org/licenses/by/ $4.0 /)$.

\begin{abstract}
This work investigated the structural, biochemical, and molecular characteristics of grape skin cell wall during ripening, related to susceptibility to Botrytis cinerea. The comparative study between the two main grape cultivars in Champagne region, Pinot noir and Chardonnay, quantified: (1) the maturity and physical profile of grape skin; (2) the morphological characteristics; (3) soluble pectic polysaccharides located in grape skin cell walls; and (4) the gene expression of the two main degrading enzymes (VvPME1 and VvPG1) and PME activity. During the maturation period, the grape skins of the two cultivars appear different in their structure and composition. Chardonnay is characterized by higher relative humidity (RH) and level of VvPG1 expression, lower disease incidence and penetrometry values, and thicker cell walls than Pinot noir skins. Thus, the cell wall composition is sufficiently different between grape varieties from the same area to allow their discrimination and could be used to better manage the harvest date.
\end{abstract}

Keywords: grape skin; cell wall; polysaccharides; Botrytis cinerea; champagne

\section{Introduction}

The grape berry skin is the outmost part of the berry, representing 5 to $18 \%$ of the fresh weight. This tissue behaves as a hydrophobic barrier which protects against UV light, dehydration, physical injuries, and pathogen infections. This is also the place of synthesis for numerous oenological compounds. The grape skin is constituted by the cuticle, the epidermis, and the hypodermis. The number of cell layers and the size of the cells are cultivar specific [1] and they evolve during ripening [2]. The grape skin cell wall composition and structure determine the shape and form of the cells, support the cell turgor pressure, regulate the intercellular communication, and provide protection against environmental factors, especially pathogens. The cell wall (CW) is a complex network composed of cellulose microfibrils embedded in a matrix of hemicelluloses, pectins, and proteins. The most abundant component of pectic polysaccharides is homogalacturonan (HG), a galacturonic acid polymer (GalA). The pectin matrix is an early target for fungal necrotrophs such as Botrytis cinerea [3]. This pathogen is considered to be one of the most important necrotrophic agents due to its large host range and its ability to cause one of the most serious diseases in grapevine, the grey mold or Botrytis bunch rot. The yield at harvest and the wine quality can both be reduced by this disease. In particular, grey 
mold can impact champagne production by the modification of its foaming properties $[4,5]$. In Champagne region, the main grape cultivars are Pinot noir and Chardonnay, which are the basis for the world-famous sparkling wine here produced. The region is characterized by a specific climate, with regular rainfall, little sunlight exposure, and a high infection rate of Botrytis cinerea disease (up to $25 \%$ ). The resistance to this disease includes many factors, preformed or induced. Constitutive elements can be physical, anatomical, or chemical constituents [6-10]. Among these features, the thickness and number of the skin cell layers [11] and the composition of the cuticle and its thickness [9,12-15] appear to be of great importance. Botrytis cinerea susceptibility depends on the cultivars $[10,15,16]$; some preformed antifungal constituents may play a role, such as tannins and phenolic compounds [11,17,18]. Moreover, the ripening process increases the disease incidence [6,19]. The onset of ripening is initiated by accumulation of sugar, softening, and increase of the grape berry size and it is followed by berry color change at veraison. From this stage, the cell wall structure and composition are evolving due to the actions of different enzymes, causing fruit softening [20]. The cell-wall-modifying enzymes including polygalacturonases (PG) and pectin methylesterase (PME) contribute to cell wall disassembly by acting on the pectin network. PMEs catalyze the hydrolysis of methyl-esters from galacturonic acids, providing the substrate for PGs. PGs hydrolyze the homogalacturonans chains of the pectin network. The combined action of these proteins promotes cell wall disassembly and increases the grape susceptibility to pathogens [21].

As exposed above, Botrytis cinerea resistance cannot be related to a single feature but is the result of a combination of several factors. A comprehensive study of the physical, biochemical, anatomical, and molecular features underlying Botrytis cinerea susceptibility in the Champagne cultivars Pinot noir (PN) and Chardonnay $(\mathrm{CH})$ has not yet been reported.

We thought that a detailed study of the grape skin cell wall factors involved in the susceptibility to Botrytis cinerea in Champagne region during the maturation period might reveal differences that would help to confirm the field knowledge and provide information about how the cell wall composition and structure differ between the two main cultivars in Champagne region, Pinot noir and Chardonnay.

\section{Materials and Methods}

\subsection{Grape Sample}

Bunches from Vitis vinifera L., cvs. Chardonnay and Pinot noir were harvested once a week, from the beginning of veraison to technological maturity from an experimental vineyard in Epernay (France). All grape samples were harvested in 2019. Thirty bunches per cultivar were picked and immediately taken to the laboratory for analysis. Then, 800 berries were cut while preserving skin integrity. For biochemical and molecular analysis, grapes were frozen with liquid nitrogen, peeled, and stored at $-80^{\circ} \mathrm{C}$ until analysis.

\subsection{Skin Characteristics}

The grape skin characteristics were determined by a combination of penetrometry measurements, relative humidity, and water activity. Grape skin firmness was determined according to Egea et al. (2006) [22], a method developed for apricots and adapted in this study to grape berries. This parameter was measured with a penetrometer (Pénéfel motorisé, SETOP Giraud Technologie, Cavaillon France) equipped with a cylindrical pointed head probe of $2.5 \mathrm{~mm}$ diameter. Grape berries were placed on a flat surface upright to the compression. Relative humidity $(\mathrm{RH})$ was measured according to Deytieux-Belleau et al. (2009) [6]. For each sample, seven berries were peeled, desiccated at $100{ }^{\circ} \mathrm{C}$ (XM60, Precisa, Poissy, France) and weighted to evaluate their relative humidity in percentage (\%RH). Moreover, water activity (Aw) measurements were performed according to Deytieux-Belleau et al. (2009) [6]. The pedicel region of a random sample of 10 berries was surrounded with paraffin to avoid exchanges to consider only those from the skin surface. The berry was placed in the chamber of the Aw-meter (Novasina, Precisa, Poissy, France) and thermoregulated to $25^{\circ} \mathrm{C}$. The stability factor was adjusted to $5 \mathrm{~min}$. 


\subsection{Cell Wall Characterization}

\subsubsection{Isolation of Cell Wall from Grape Skin}

The cell wall isolation was performed according to Geny et al. (2003) [23], adapted to the grape skin material. One hundred frozen berries were peeled to isolate the skins, and these were ground in a mortar under liquid nitrogen to obtain a powder, then suspended in $10 \mathrm{~mL}$ of $0.2 \mathrm{M}$ Tris- $\mathrm{HCl}$ buffer ( $\mathrm{pH} 7.5)$ containing $2.5 \%$ of EDTA $(w / v)$, then homogenized and centrifuged at $15,000 \times g$ rpm for $20 \mathrm{~min}$; the resulting pellet was resuspended in $10 \mathrm{~mL}$ of the buffer and centrifuged at $15,000 \times \mathrm{g} \mathrm{rpm}$ for $30 \mathrm{~min}$. The pellet was then suspended twice in $10 \mathrm{~mL}$ of $2.5 \mathrm{M}$ saccharose and centrifuged at $30,000 \times g$ and $50,000 \times g \mathrm{rpm}$ for $30 \mathrm{~min}$. The pellet was then suspended in $10 \mathrm{~mL}$ of saccharose and centrifuged at different speeds: $5000 \times g$ rpm $30 \mathrm{~min} ; 15,000 \times g \mathrm{rpm} 30 \mathrm{~min} ; 25,000 \times g \mathrm{rpm} 30 \mathrm{~min}$; $50,000 \times g \mathrm{rpm} 1 \mathrm{~h}$. The pellet was resuspended six times in the homogenization buffer, then in $10 \mathrm{~mL}$ of Triton X-100 $0.1 \%$ and centrifuged at $3000 \times \mathrm{g}$ rpm $10 \mathrm{~min}$. Finally, the pellet was resuspended in Tris- $\mathrm{HCl}$ buffer and centrifuged at $2000 \times \mathrm{g} \mathrm{rpm} 5 \mathrm{~min}$, then filtered through $3 \mu \mathrm{m}$ and dried in an oven at $35^{\circ} \mathrm{C}$ for at least $16 \mathrm{~h}$. This fraction was designated as the cell wall fraction of the skin.

2.3.2. Extraction and Spectrophotometric Analysis of Polysaccharide Fractions of Cell Wall from Grape Skin

Sequential extractions of cell wall component according to Saulnier et al. (1988) [24] adapted to grape skin were performed. The cell wall fractions underwent different extractions to release the soluble polysaccharides according to their chemical bonds, with $20 \mathrm{~mL}$ of distilled water, ammonium oxalate $2 \%, \mathrm{HCl} 0.05 \mathrm{~N}$, and $\mathrm{NaOH} 0.05 \mathrm{~N}$. The extractions were stopped by centrifugations at $15,000 \times \mathrm{g}$ for $30 \mathrm{~min}$ and the supernatants were collected as WSP, OXSP, HSP, and OHSP fractions, respectively. The supernatants were diluted at $1 / 10 \mathrm{e}$ for the spectrophotometric analysis.

The analysis of polysaccharides was adapted from Robertson (1979) [25]; this method is based on the analysis of galacturonic acid by acid hydrolysis of cell wall fractions. The total polysaccharide content was estimated as galacturonic acid using a calibrating curve.

\subsubsection{Analysis of Polysaccharides by HPSEC}

The molecular mass distribution of grape skin polysaccharides was established by high-performance size-exclusion chromatography (HPSEC) according to the previous work of Apolinar-Valiente et al. (2014), Guadalupe et al. (2012), and Watrelot et al. (2013) [26-28]. The system was composed of an SIL-20AC sampling injector and an LC-20AD pump (Shimadzu Corporation, Kyoto, Japan). Polysaccharides were analyzed using Agilent PL aquagel-OH $8 \mu \mathrm{m}$ and Agilent PL aquagel-OH $205 \mu \mathrm{m}(300 \times 7.5 \mathrm{~mm})$ connected to an SPD-20AV UV/VIS detector (Shimadzu Corporation, Kyoto, Japan) and refractive index indicator (RID-20A; Shimadzu Corporation, Kyoto, Japan), at $0.6 \mathrm{~mL} / \mathrm{min}$ flow rate in ammonium formate buffer. The MM of the grape skin polysaccharides was calculated from the calibration curve established with Pullulan calibration kit (P-800, $\mathrm{MM}=642,000$; $\mathrm{P}-400, \mathrm{MM}=380,000 ; \mathrm{P}-200, \mathrm{MM}=194,000 ; \mathrm{P}-100, \mathrm{MM}=107,000 ; \mathrm{P}-50, \mathrm{MM}=47,100$; P-20, $\mathrm{MM}=22,000 ; \mathrm{P}-10, \mathrm{MM}=9800 ; \mathrm{P}-5, \mathrm{MM}=6300$; Showa Denko, Tokyo, Japan). The calibration equation was $\mathrm{ax}^{3}+\mathrm{bx}^{2}+\mathrm{cx}+\mathrm{d}$; with $\mathrm{a}=0.002, \mathrm{~b}=0.132, \mathrm{c}=3.942, \mathrm{~d}=36.659$, and $\mathrm{x}=\mathrm{x}-\mathrm{T}_{\text {Lim }}$.

\subsection{Extraction of Total RNA and Gene Expression Analysis}

Total RNA was isolated as described in Reid et al. (2006) [29] from one gram of frozen grape skin, then treated with DNase TURBO (Invitrogen) and purified. The quality of RNA was verified by the absorbance ratios of 1.8 to 2.0 and by the demonstration of intact ribosomal bands with agarose gel electrophoresis. Total RNA was reverse transcribed using Superscript III reverse transcriptase (Invitrogen Life Technologies). The amplification reactions were performed using a CFX Connect thermocycler (Bio-Rad, Berkeley, CA, USA) and the SYBR Green Supermix (Bio-Rad) according to the manufacturer's protocol. 
Real-time PCR conditions were: $95{ }^{\circ} \mathrm{C}$ for $3 \mathrm{~min}, 40$ cycles of $95{ }^{\circ} \mathrm{C}$ for $10 \mathrm{~s}, 60{ }^{\circ} \mathrm{C}$ for $30 \mathrm{~s}$, and $72{ }^{\circ} \mathrm{C}$ for $30 \mathrm{~s}$, and a melting curve from $60^{\circ} \mathrm{C}$ to $95^{\circ} \mathrm{C}$ at $0.5^{\circ} \mathrm{C}$ increments was introduced. The primers PME1 (5'-GGCACCGTCGATTTCATATT-3 $\left.{ }^{\prime}\right)$ and PG1 (5' GATCCCAGAAGGTGCAAGT-3') were used for real-time PCR of VvPME1 and VvPG1. The relative expression level corresponding to the mean of three replicates was normalized against the expression level of VvUbiquitin1 gene (TC32075). The normalized expression of target genes was expressed by the difference between the cycle threshold $(\mathrm{Ct})$ of the target gene and the $\mathrm{Ct}$ of $V v U B I, \Delta \mathrm{Ct}=\Delta \mathrm{CtTarget}-\Delta \mathrm{CtUBI}$, corresponding to the $2-\Delta \mathrm{Ct}$ method.

\subsection{Determination of PME Activity}

According to the previous work of Lacampagne (2010) [30], PME (EC. 3.1.1.11) activity was performed with frozen skins extracted with $25 \mathrm{mM}$ sodium chloride $\left(\mathrm{CaCl}^{2}\right)$ buffer, $0.1 \mathrm{M}$ of HEPES, $1 \%(w / v)$ polyethylene glycol $600,1 \%(w / v)$ sucrose, $100 \mathrm{mM}$ dithiothreitol (DTT), and $500 \mu \mathrm{L} / \mathrm{L}$ of protease inhibitor cocktail. Two grams of powdered grape skins was placed into $3 \mathrm{~mL}$ of extraction buffer and $200 \mathrm{mg}$ of polyvinylpolypyrrolidone (PVPP) and stirred for $3 \mathrm{~h}$ at $4{ }^{\circ} \mathrm{C}$. The protein extracts were centrifuged at $18,000 \times g, 4^{\circ} \mathrm{C}$ for $30 \mathrm{~min}$. The resulting supernatant was considered to be the crude extract, adjusted to $\mathrm{pH}$ 7.5. The activity was determined by the methanol production according to DeytieuxBelleau et al. (2008) [6] The amount of methanol released allowed the determination of PME activity expressed in katal, using a calibration curve of methanol.

\subsection{Transmission Electron Microscopy Analysis of Grape Skin}

Berries from 10 bunches were collected and prepared for transmission electron microscopy (TEM) analysis. The grape berries were cut into small pieces and placed in a $2 \%$ glutaraldehyde solution (Sigma-Aldrich, Germany) for one night at $4{ }^{\circ} \mathrm{C}$. After a washing step in phosphate buffer, the samples were post-fixated in a $1 \%$ PFA solution containing $0.01 \%$ of sodium azide and stored at $4{ }^{\circ} \mathrm{C}$. Following the method of Robertson et al. (1992), the samples were dehydrated in ethanol of increasing concentrations $(30 \%, 50 \%, 70 \%, 95 \%$, and 100\%), embedded in HM20 resin (Delta Microscopies, Mauressac, France) and polymerized for three days at $-35{ }^{\circ} \mathrm{C}$. Using a diamond knife (Diatome, Bienne, Switzerland) and an ultramicrotome (Leica, Vienna, Austria), ultrathin sections were obtained, placed on nickel grids, and examined with TEM Hitachi H7650 electron microscope coupled with Gatan Orius SC1000 camera (Gatan, Inc., Pleasanton, CA, USA).

\subsection{Botrytis cinerea Infection Tests}

The Botrytis cinerea infection tests were performed according to Martínez and FernándezTrujillo (2007) [31]. The strain B05.10 was used to assess the infection tests, provided by INRAE of Versailles. Two samples of twenty berries were removed individually with the pedicel attached, rinsed in deionized water, and dried. Berries were placed on a grid within incubation chambers consisting of plastic boxes containing absorbent paper with $15 \mathrm{~mL}$ of water. Mycelial plugs were cut from 2-week-old colonies of $B$. cinerea grown on potato dextrose agar (PDA) in a thermoregulatory chamber. The plugs were placed individually on berries and placed in a thermoregulatory chamber with alternating day and night periods. Symptom development was assessed as a descriptive scale (healthy/rotten). The disease incidence was evaluated by the mean percentage of rotten berries. To evaluate the presence of the pathogens on grapes, a control was performed with berries incubated without plugs in the same conditions.

\subsection{Statistical Analysis}

All measurements were performed in triplicate; the values presented in graphs represent the means of the replications \pm standard error of the mean. The results were statistically compared with one-way ANOVA, followed by Tukey's HSD test using JMP ${ }^{\circledR}$ (version 14.2.0, SAS Institute Inc., Cary, NC, USA, 1989-2019). Statistical tests were performed at $95 \%$ confidence intervals. 


\section{Results and Discussion}

\subsection{Grape Maturity}

Grape berries from the two main cultivars in Champagne region were harvested during 2019 vintage, prior to veraison until harvest. Biochemical parameters (Table 1) were used to characterize the development of berries, and similar changes were observed for both cultivars: increase of potential alcohol and increase of the amount of skin material per berry. The length of the maturation period differs between the two cultivars, until 78 days after anthesis (DAA); both cultivars showed the same evolution, then potential alcohol remained stable for Pinot noir grapes while it increased for Chardonnay grapes, reaching $111 \%$ vol. at harvest.

Table 1. Grape berry characteristics.

\begin{tabular}{cccc}
\hline \multirow{2}{*}{$\begin{array}{c}\text { Cultivar } \\
\text { Chardonnay }\end{array}$} & Days after Anthesis & $\begin{array}{c}\text { Potential Alcohol } \\
\text { (\% vol.) }\end{array}$ & Skin Material (mg/Berry) \\
& 65 & 4.7 & 101.3 \\
& 72 & 8.2 & 107.8 \\
& 79 & 9.5 & 122.1 \\
Pinot noir & 85 & 10.4 & 135.1 \\
& 89 & 11.1 & 137.7 \\
& 71 & 5.4 & 113.1 \\
& 78 & 7.0 & 114.9 \\
& 84 & 9.5 & 124.8 \\
& 88 & 8.1 & 108.3 \\
\hline
\end{tabular}

\subsection{Physical and Structural Changes in Skins}

Structural properties of cell walls determine the mechanical resistance and texture of ripening berries. Better understanding of the changes that occur during the grape berry development and softening, factors that influence berry susceptibility to Botrytis bunch rot, may have considerable importance in grape berry quality and harvest optimization. By physical parameters, grape berry texture can be evaluated. Figure 1 shows the evolution of the force required to penetrate the grape skin evaluated by penetrometry, at each time of the maturation period. Pinot noir showed the highest values of penetrometry throughout ripening, while Chardonnay showed lower values at each time. These results confirm previous works; penetrometry measurements are cultivar specific [30,32]. Relative humidity (Figure 2) of skins showed a decrease during ripening for both cultivars. However, RH was higher at each stage for Chardonnay skins than Pinot noir ones; the cultivar's influence has already been reported for this parameter [33]. Figure 3 shows the evolution of water activity at each time of development, which decreases progressively during grape berry development from 0.94 to 0.92 for both cultivars, as reported by Deytieux-Belleau et al. (2009) and Fermaud et al. (2011) [6,8]; this shows the increase of grape porosity, which influences the grape berry susceptibility to pathogens [34].

Transmission electron microscopy (TEM) observations showed the exocarp ultrastructure of both cultivars at veraison (A and $C$ ) and harvest (B and D). The grape skin consists of a layer of cuticle that covers the epidermis and the underlying outer hypodermis [35-37] that can be distinguished in Figure 4: (i) the cuticle (C), (ii) the epidermis (E) with cubic and regular cells, moderate thick walls and separated from the pulp by (iii) the hypodermis $(\mathrm{H})$, composed of elongated cells whose size increases towards the pulp. For both cultivars and stages, the cell wall thickness appears to increase from epidermis to hypodermis as already reported $[30,35,38]$ and Pinot noir cell walls are clearly thinner than Chardonnay ones. 


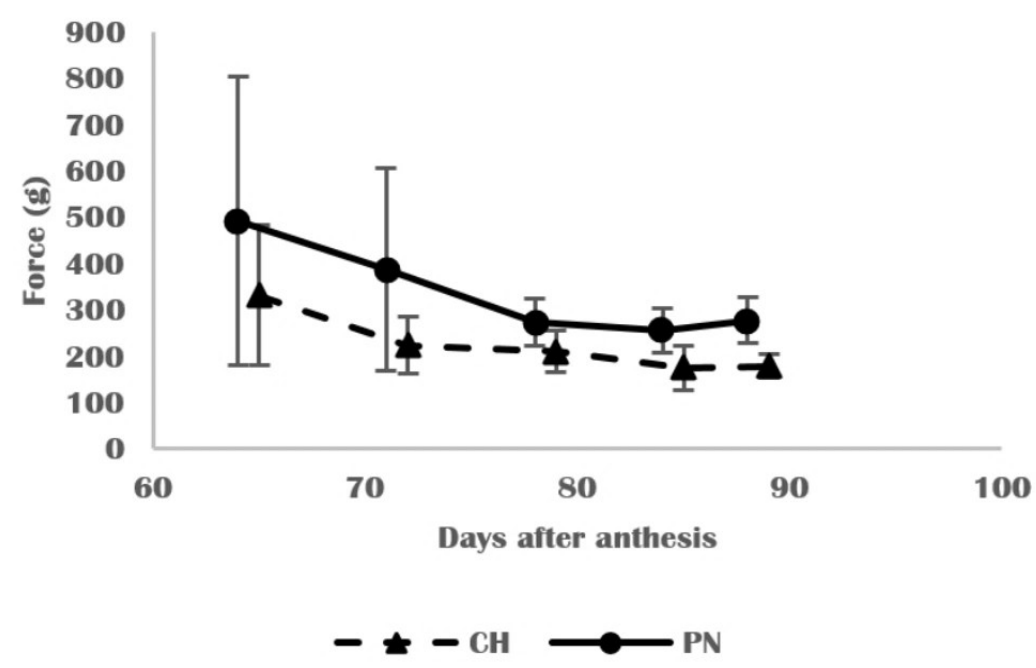

Figure 1. Penetrometry measurements expressed in force $(\mathrm{g})$ for grape skin from Pinot noir $(\bullet)$ and Chardonnay $(\boldsymbol{\Lambda})$ grapes. Means of 30 replications \pm SD.

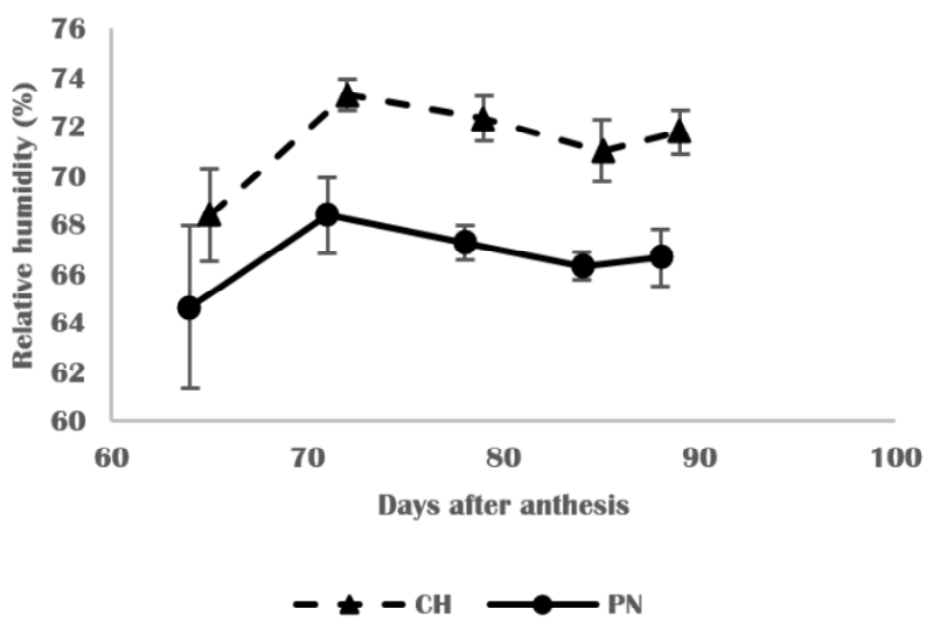

Figure 2. Relative humidity $(\mathrm{RH} \%)$ in grape skin from Pinot noir $(\bullet)$ and Chardonnay $(\boldsymbol{\Delta})$ grapes. Means of 3 replications \pm SD.

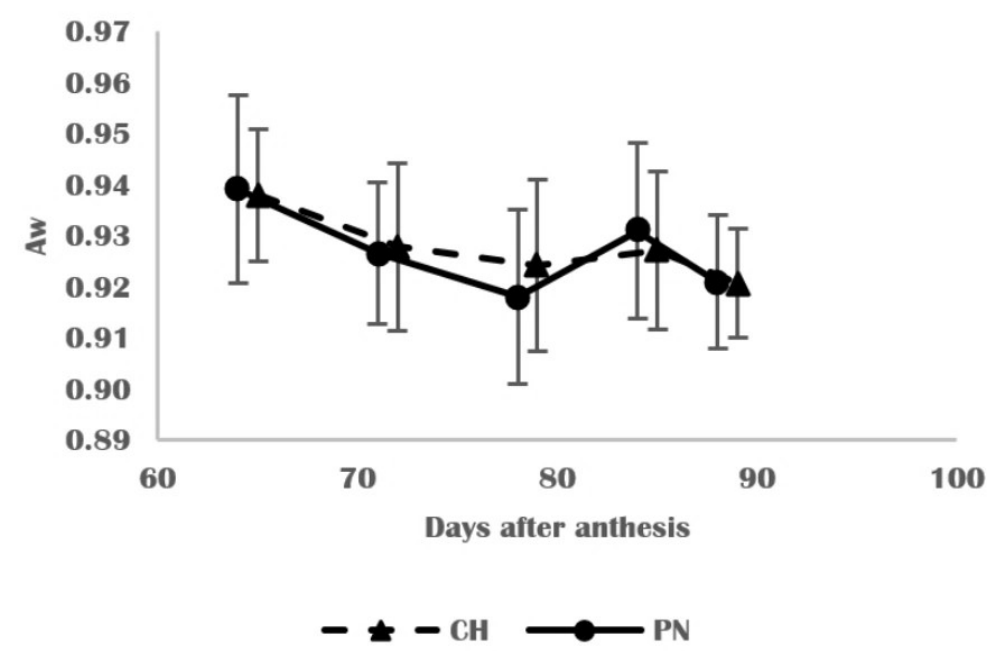

Figure 3. Water activity $(\mathrm{Aw})$ from Pinot noir $(\bullet)$ and Chardonnay $(\boldsymbol{\Lambda})$ grapes. Means of 10 replications $\pm S D$. 
At veraison, skin cell wall organization differs according to the cultivars: Chardonnay skins showed regular and cubic epidermal cells which contain several vacuoles and hypodermal cells which are characterized by some tannin-rich vacuoles. Pinot noir skins showed epidermal cells tangentially elongated, with hypodermal cells showing tanninrich vacuoles with dense tannins. With ripening, epidermal cells were tangentially and radially elongated; cell wall thickness did not change from the previous stage. Changes of tannin-rich vacuole type are observed with tannins deposited against the wall. Pinot noir exocarp showed an accumulation of dense tannins in epidermal cells and tannins-rich vacuole, with one heap filling all the space of the cell being notable.
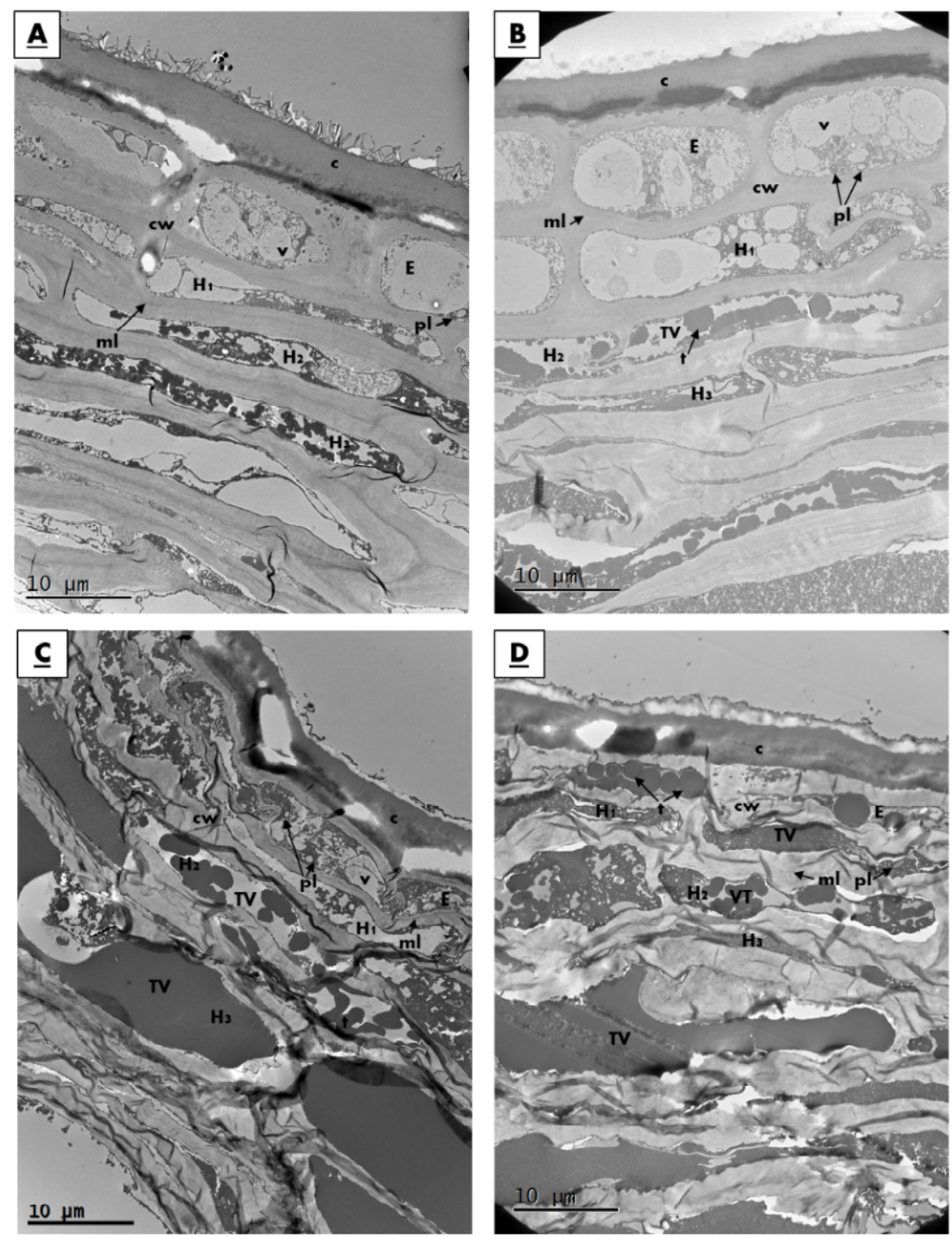

Figure 4. Ultrastructure observations of grape skin from Chardonnay $(\mathbf{A}, \mathbf{B})$ and Pinot noir $(\mathbf{C})$ and (D) at veraison $(\mathbf{A}, \mathbf{C})$ and harvest $(\mathbf{B}, \mathbf{D})$. Scale bar $=10 \mu \mathrm{m} ;(\mathbf{C})$ : cuticle; E: epidermis; H1: hypodermis 1; H2: hypodermis 2; H3: hypodermis 3; cw: cell wall; pl: plastids; ml: middle lamella; v: vacuole; TV: tannins-rich vacuole.

Skin cell wall size (thickness) was obtained (Figure 4) as the sum of the thickness of all the four layers (E, H1, H2, H3) as shown in Table 2. Chardonnay is significantly different from Pinot noir, with thicker skin cell walls as observed previously. These results confirm that grape genotypes are characterized by differences in ultrastructural features of the skin affecting physical and mechanical properties of berries [10,36]. It is known that grape skin morphology is cultivar specific as reported by Ortega-Regules et al. in (2008) [1]. Moreover, these characteristics can modulate the susceptibility to Botrytis cinerea; the number and 
the thickness of epidermal and hypodermal cell layer have been reported to be positively correlated with Botrytis cinerea resistance [10].

Table 2. Thickness of grape berry skin cell wall layers measured at veraison and harvest. Data represent the means ( \pm confidence intervals) of twenty-five measurements performed on Chardonnay and Pinot noir samples. Letters represent the result of a Tukey's HSD test after one-way ANOVA $(p \leq 0.05)$ analysis to find differences between cultivars.

\begin{tabular}{ccccc}
\hline \multirow{2}{*}{ Measured Parameters } & \multicolumn{2}{c}{ Veraison } & \multicolumn{2}{c}{ Harvest } \\
\cline { 2 - 5 } & Chardonnay & Pinot Noir & Chardonnay & Pinot Noir \\
\hline Epidermis $(\mu \mathrm{m})$ & $1.23 \pm 0.11 \mathrm{a}$ & $0.95 \pm 0.06 \mathrm{a}$ & $1.14 \pm 0.12 \mathrm{a}$ & $0.94 \pm 0.07 \mathrm{a}$ \\
Epidermis-Hypodermis 1 $(\mu \mathrm{m})$ & $1.65 \pm 0.17 \mathrm{~b}$ & $1.13 \pm 0.11 \mathrm{a}$ & $1.55 \pm 0.16 \mathrm{~b}$ & $1.22 \pm 0.10 \mathrm{~b}$ \\
Hypodermis 1-Hypodermis 2 $(\mu \mathrm{m})$ & $2.03 \pm 0.28 \mathrm{c}$ & $1.59 \pm 0.15 \mathrm{~b}$ & $1.70 \pm 0.14 \mathrm{~b}$ & $1.46 \pm 0.11 \mathrm{c}$ \\
Hypodermis 2-Hypodermis 3 $(\mu \mathrm{m})$ & $2.39 \pm 0.22 \mathrm{c}$ & $1.89 \pm 0.22 \mathrm{c}$ & $2.04 \pm 0.28 \mathrm{c}$ & $2.22 \pm 0.16 \mathrm{~d}$ \\
\hline
\end{tabular}

\subsection{Chemical Changes in Skin Cell Wall}

Fruit softening during ripening is associated with changes in cell wall structure and composition. These changes may affect the mechanical and technological properties of grape skin. A decrease in neutral sugars and changes in pectic polysaccharides are the main features [39]. The quantity of isolated galacturonic acid (Figure 5) from grape skin cell wall increased during ripening for both cultivars. Pectin content in Chardonnay skin cell walls did not vary and slightly increased at harvest while in Pinot noir cell walls, pectin content increased at veraison to reach the maximum of $1.66 \mathrm{mg} \mathrm{GA} / \mathrm{g}$ FM at harvest. The decrease of pectin content in skin cell walls has been reported [40] and seems to be related to the increase of cell volume, with the cell walls becoming thinner at the end of maturation, which is not seen in this study, explained by an early harvest. In other fruits, firmer cultivars presented a higher quantity of cell wall material [41,42] and higher susceptibility to pathogens [3]. To go further, skin cell wall fractions have been extracted with different solutions (water: WSP; oxalate: OXSP; sodium: OHSP; acid: HSP) to break chemical bonds between pectic polysaccharides. Weak bonds correspond to covalent bonds while strong bonds are represented by ionic bonds. For each type of bond, the size of soluble polysaccharides has been evaluated for both cultivars.
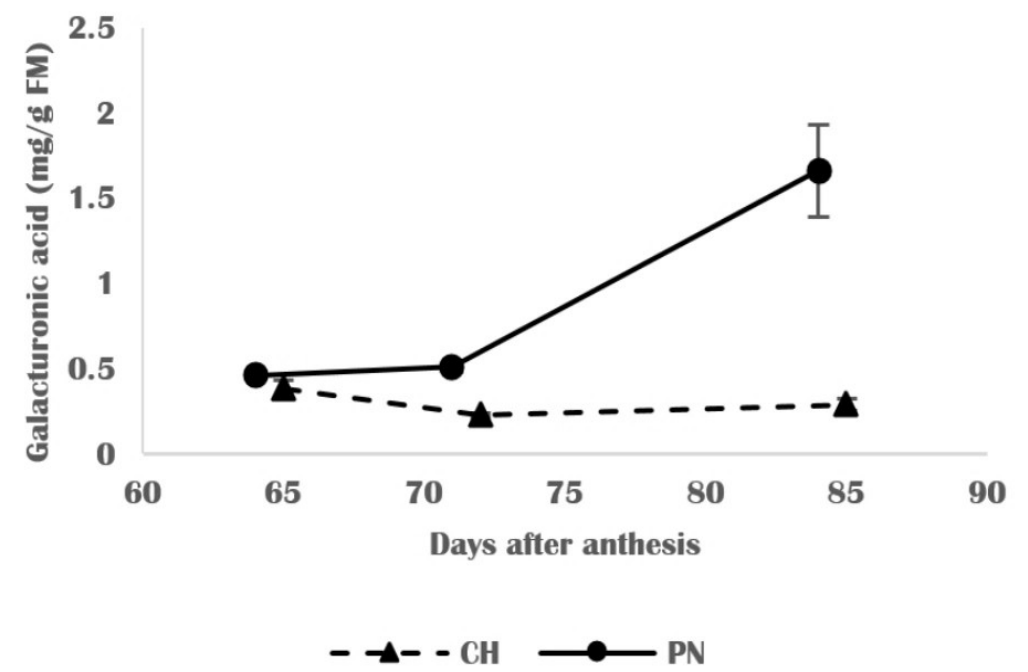

Figure 5. Galacturonic acid content for Pinot noir $(\bullet)$ and Chardonnay (\) skin cell walls during ripening. Means of 3 replications $\pm S D$.

Figure 6 shows that the size of polysaccharides depends on the stage of development. For both cultivars, proportion evolution shows the same pattern: increase of proportion 
of high molecular weight polysaccharides at veraison and then a decrease. At harvest, medium molecular weight polysaccharides $(380 \mathrm{kDa}-47 \mathrm{kDa})$ were in the majority for both cultivars but the proportion of high molecular weight polysaccharides was much higher in Pinot noir cell walls (29\%) than Chardonnay ones (9\%). The proportion of small polysaccharides is similar in both cultivars, representing $14 \%$ to $20 \%$ of all polysaccharides extracted. This result suggests that polysaccharide accumulation and degradation in cell walls depend on cultivars and highlights specific mechanisms for each variety during ripening, by degrading enzymes such as pectin methyl esterase (PME) and polygalacturonase (PG).

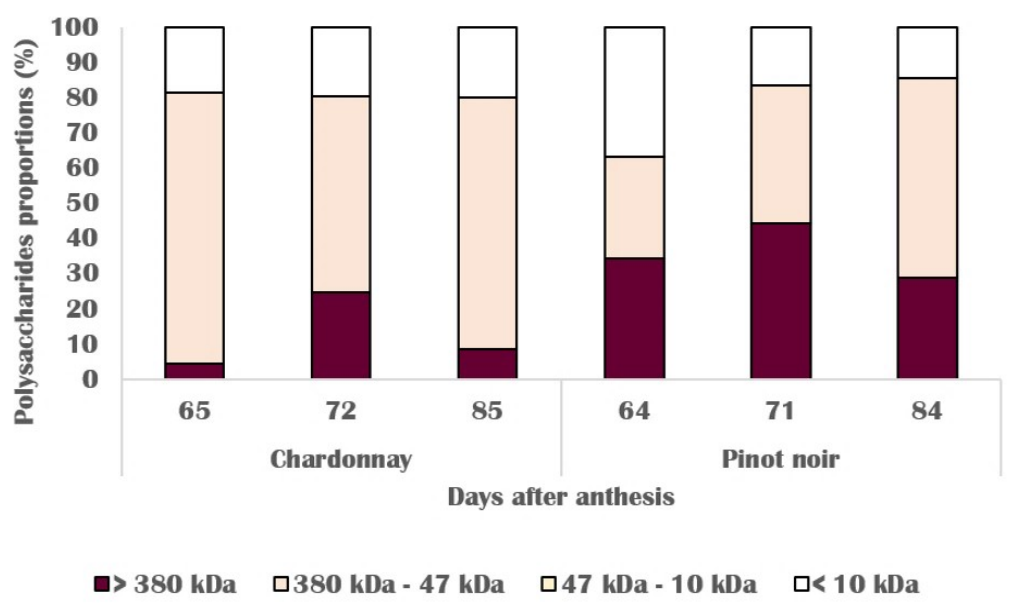

Figure 6. Proportions of pectic polysaccharides for Pinot noir and Chardonnay skin cell walls during ripening.

Moreover, Figures 7 and 8 show that the majority of high molecular weight polysaccharides are extracted by breaking the strong bonds in Pinot noir cell walls. At harvest, all the tightly bound high molecular weight polysaccharides are extracted from Chardonnay cell walls while Pinot noir cell walls still show $75 \%$ of high molecular weight polysaccharides. These results suggest that Pinot noir polysaccharides with a high MW are tightly bound to the cell wall and may participate in cell wall rigidity by $\mathrm{Ca}^{2+}$ bridges with homogalacturonans [43] depolymerized due to pectin methylesterase (PME). The depolymerization of homogalacturonans results in the production of free galacturonic acid units which can form "egg-box" junctions, a calcium cross-linkage between homogalacturonans chains, resulting in pectin stiffening [44].

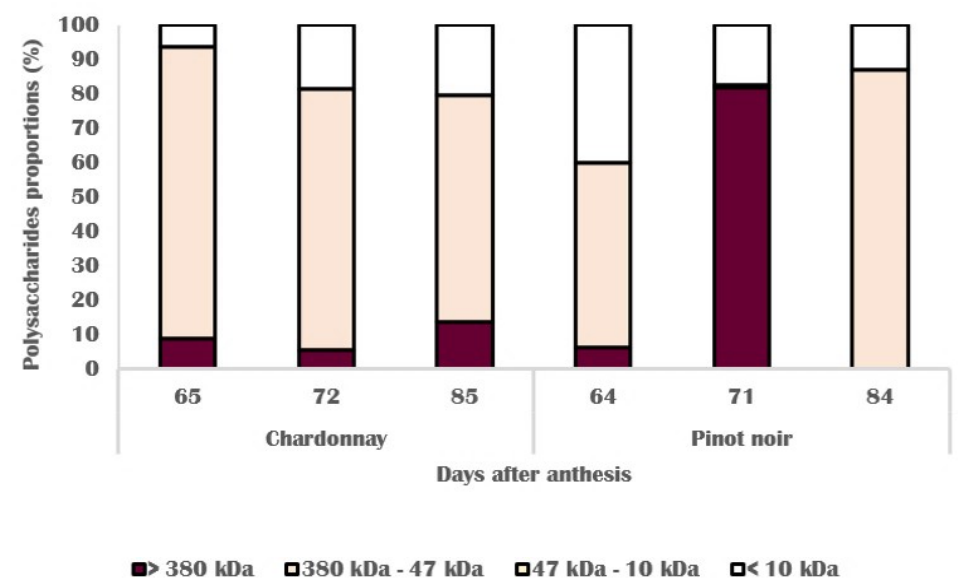

Figure 7. Proportions of pectic polysaccharides according to their molecular mass in weak bonds for Pinot noir and Chardonnay skin cell walls. 


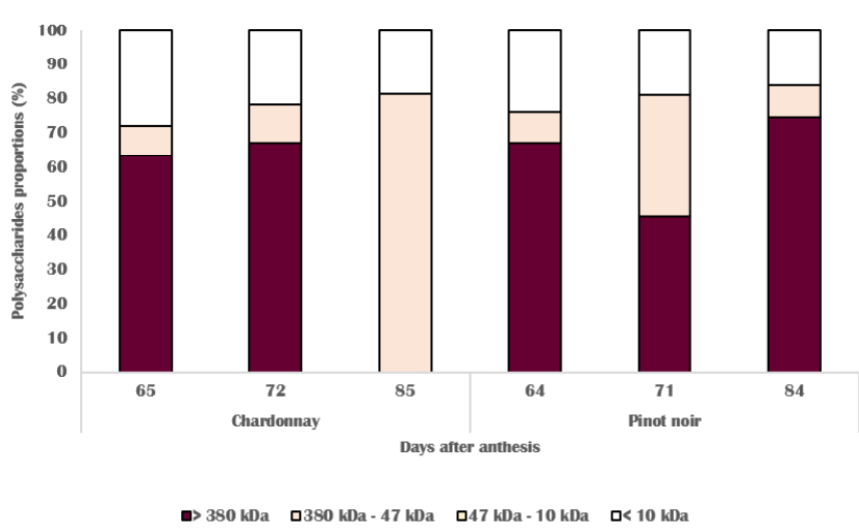

Figure 8. Proportions of pectic polysaccharides according to their molecular mass in strong bonds for Pinot noir and Chardonnay skin cell walls.

\subsection{Molecular and Biochemical Changes in Skin Cell Walls}

The activity of the cell-wall-associated PME enzyme was detected in all the ripening stages analyzed until harvest (Figure 9). Before veraison, 0.5 nkat and 0.3 nkat per gram of skin were detected for Pinot noir and Chardonnay skins, respectively. In Pinot noir skins, the activity decreased until $0.37 \mathrm{nkat} / \mathrm{g}$ skin at veraison, then increased until harvest, as reported in Cabernet sauvignon from Bordeaux [45]. The expression of VvPME1 in Pinot noir was not detected before veraison, while in Chardonnay skins, VvPME1 was only detected at veraison (72 DAA) and before harvest (85 DAA) as shown in Figure 10. For both cultivars, VvPME1 was expressed at veraison. In Pinot noir skins, the expression progressively increased until harvest, while in Chardonnay skins, the gene was expressed at 85 DAA. The expression pattern in ripening skins was temporally correlated with the pattern of PME activity: for Chardonnay skins, the high level activity corresponded to the expression of $V v P M E 1$; in Pinot noir, the progressive increase of PME activity was also observed for $V v P M E 1$ expression.

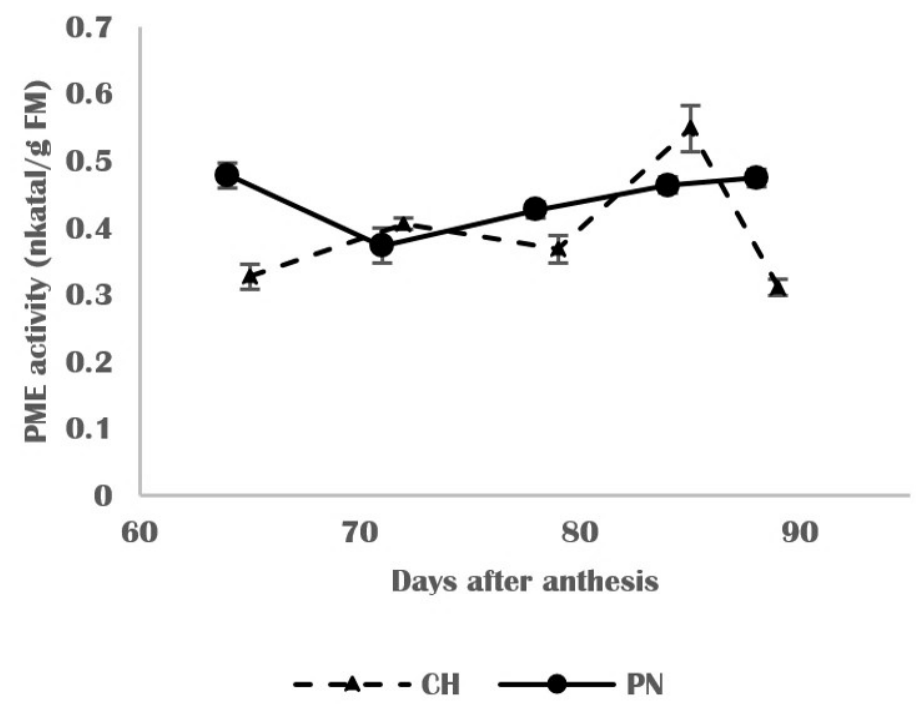

Figure 9. PME activity in grape skin from Pinot noir $(\bullet)$ and Chardonnay $(\boldsymbol{\Lambda})$ grapes during ripening. Means of 3 replications \pm SD.

Changes in the pectin matrix are factors that impact cell wall structure during grape ripening. In this context, PME plays a role in the firmness and softening of the cell walls by remodeling and disassembly of the pectin matrix $[20,46]$. These results agreed with those on Cabernet sauvignon [45], where PME activity showed a decrease after the color change period and an increase during ripening, as observed in Chardonnay and Pinot noir skins. 
However, the variation of activity pattern between cultivars suggests different rates of evolution of cell wall homogalacturonans during the maturation period and may be related to the differences of cell wall thickness observed in this study (Figure 4). Moreover, the PME determines the susceptibility of the galacturonans to degradation by polygalacturonases; the combined action of PME and PG has been suggested.

The expression of $V v P G 1$ has been investigated; the gene was detected until harvest for Chardonnay skins (Figure 11). VvPG1 was not detected before veraison for Pinot noir skins and showed a very faint signal from 72 to 89 DAA which remained stable during the maturation period. In Chardonnay skins, VvPG1 transcripts were highly accumulated during the color change period and showed the highest accumulation at veraison and decreased progressively until harvest. The expression patterns of polygalacturonase genes have been extensively studied due to their well-known role during fruit ripening [47]. These results suggest that $V v P G 1$ is involved in the veraison process [45]; a recent finding showed the difference in expression pattern of several polygalacturonases genes according to different grape tissues [47].

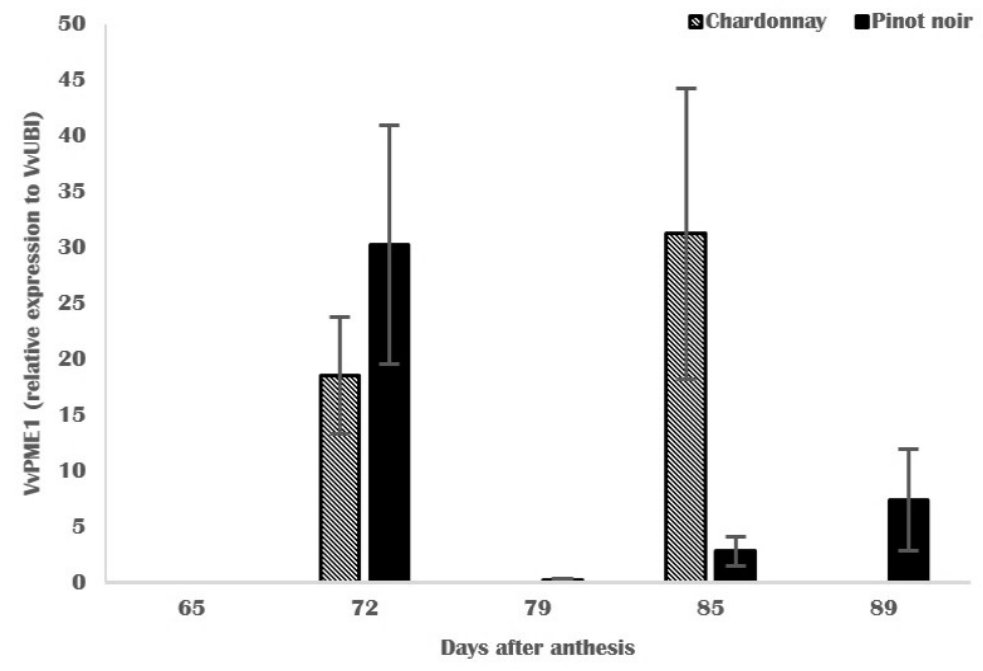

Figure 10. Gene expression of $V v P M E 1$ in Pinot noir and Chardonnay skins during ripening. Means of 3 replications $\pm \mathrm{SD}$.

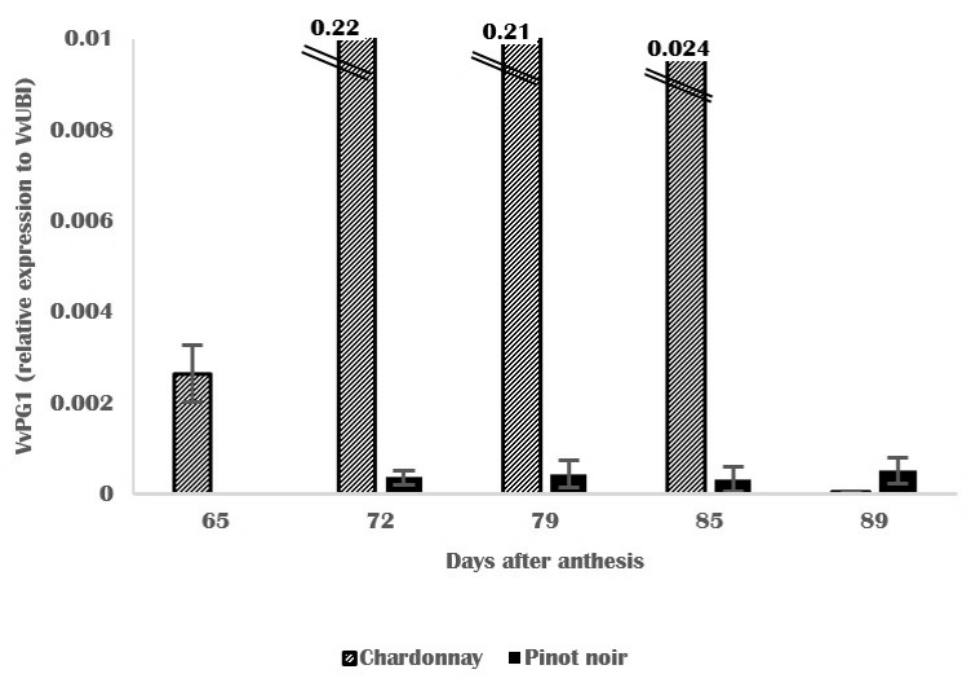

Figure 11. Gene expression of $V v P G 1$ in Pinot noir and Chardonnay skins during ripening. Means of 3 replications \pm SD. 


\subsection{Grape Berry Susceptibility to Botrytis cinerea}

Under our experimental conditions for Pinot noir and Chardonnay, the epidemic curve progress was characterized by an incidence of Botrytis bunch rot that increased from veraison onwards (Figure 12). The disease incidence reached $72 \%$ of rotted clusters 10 days after veraison and remained stable until harvest for Pinot noir grapes, while in Chardonnay, the disease incidence increased progressively to reach $58 \%$ of rotten clusters. The length of the disease incidence differed between Chardonnay and Pinot noir; at harvest, Chardonnay grapes were less infected than Pinot noir grapes. These results suggest that Pinot noir and Chardonnay grapes are both susceptible to botrytis bunch rot, as reported by the recent work of Paňitrur-De La Fuente et al. (2018) [16] and that Chardonnay grapes are less susceptible to Botrytis cinerea, at each time of maturation period, than Pinot grapes, in Champagne region.

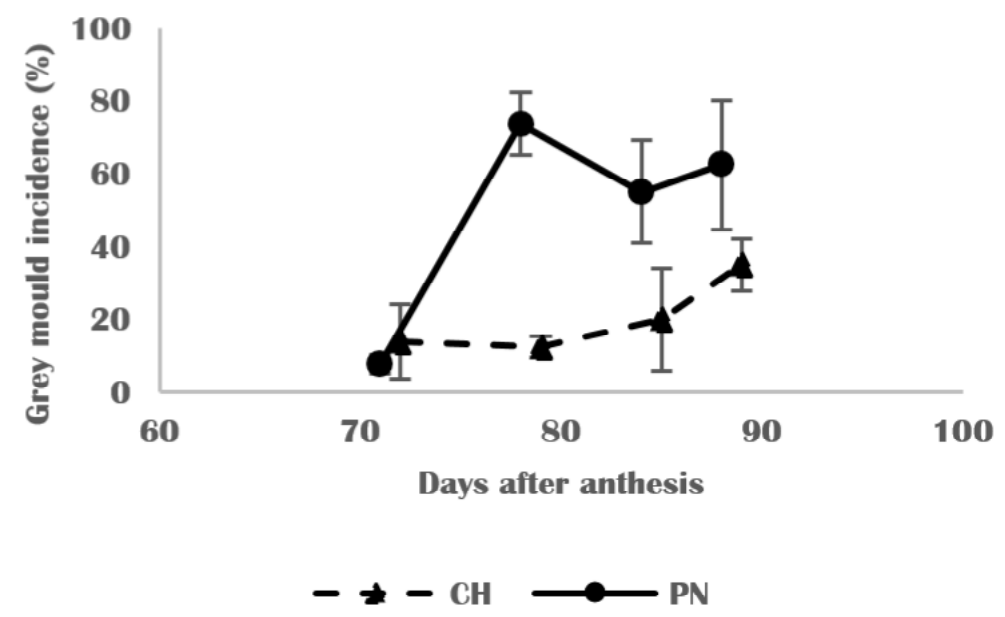

Figure 12. Disease incidence (\%) of Pinot noir $(\bullet)$ and Chardonnay $(\mathbf{\Lambda})$ grapes during ripening.

\subsection{Linkage between Grape Skin Cell Wall Features and Botrytis cinerea Infection}

The cell wall of grape berries, especially from the first cell layer of the skin, forms a diffusion barrier for many oenological compounds, including tannins. Grape cell walls are also the source of pectic polysaccharides, arabinans and arabinogalactan proteins (AGP), homogalacturonans (HG), and rhamnogalacturonans (RG-I and RG-II). Structural properties of cell walls determine the mechanical and environmental resistance and the texture of ripening berries. Better understanding of the changes that occur during the grape berry development and softening, factors that influence berry susceptibility to Botrytis bunch rot, may have considerable importance in grape berry quality and harvest optimization. In addition, the degradation and solubilization of pectic polysaccharides are known to be involved in fruit softening [48] and the increase of fruit susceptibility [21]. Veraison was indicated by the decrease of relative humidity (Figure 2) and penetrometry values (Figure 1) associated with the increase of potential alcohol (Table 1) and Botrytis cinerea incidence (Figure 12). Grape berry development is divided into two growth periods separated by a lag phase. The first period is characterized by a period of intense cell division and accumulation of organic acids [49] which reach the maximum during the lag phase. Veraison initiates the second growth period and is characterized by several changes affecting berries: softening followed by an acceleration of growth linked to the accumulation of sugars. The softening results in changes in cell wall structure and composition [50,51] due to cell-wall-modifying enzymes $[20,52]$ such as pectin methylesterase (PME) and polygalacturonase (PG) $[40,53]$. These enzymes participate in depolymerization and solubilization of pectic polysaccharides, leading to grape skin cell wall weakness and more susceptibility to pathogen entry. These results clearly show that major changes associated with grape berry ripening, such as softening and sugar accumulation, coincide with physical parameters (penetrometry, RH, and Aw), cell wall structural changes (Figure 4), and the composition 
and gene expression of the main cell-wall-degrading enzymes. We thought it would be interesting to use cell wall components, physical parameters, and disease incidence as variables to discriminate varieties, to ascertain whether the cell wall parameters were sufficiently different between varieties to differentiate them. For this, a principal component analysis was used (Figure 13).

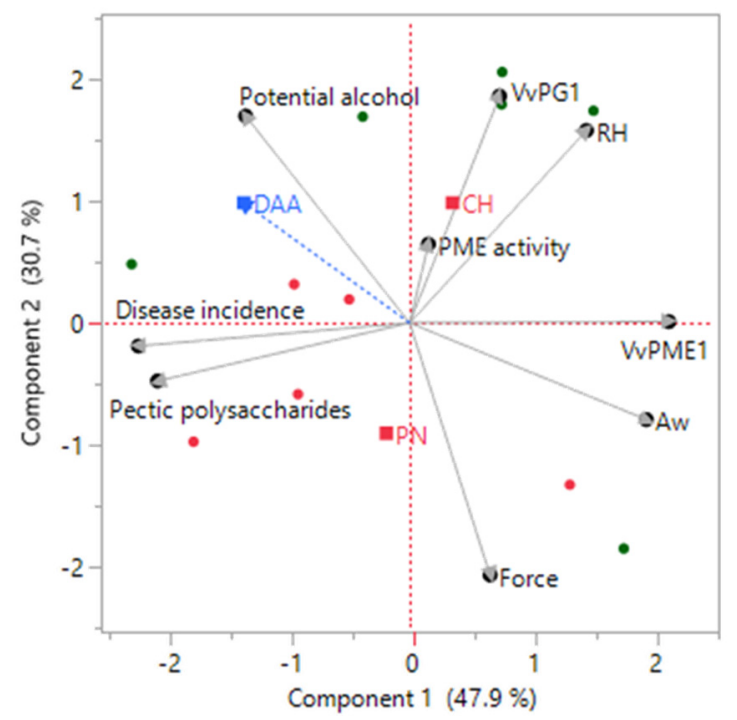

Figure 13. Principal component analysis of Chardonnay $(\bullet)$ and Pinot noir $(\bullet)$ varieties for different ripening stages according to the first and second components.

Two discriminant components were established, which allowed $78.6 \%$ of the total variance of the samples, meaning that the two cultivars were well represented by skin cell wall parameters under this study, and may be discriminated by these parameters. Chardonnay skins were mainly represented by high RH, notable expression of $V v P G 1$, and a softer skin which is easily penetrable, while Pinot noir skins were characterized by a high amount of pectic polysaccharides, a firmer skin, and a faint expression of $V v P G 1$. These differences, together with the differences in cell wall morphology observed by microscopy, could explain Pinot noir's higher susceptibility to Botrytis cinerea during ripening (Figure 12).

In the long term, these results will make it possible to establish a profile of grape skin maturation in relation to the risk of Botrytis cinerea rot. The evaluation of the skin texture (penetrometer, aw) linked to a threshold value of Botrytis cinerea rot could allow the development of a rot risk scale according to the skin composition, conditioned by the climatic conditions.

\section{Conclusions}

This study has shown that cell wall composition is sufficiently different between grape varieties from the same area to allow their discrimination. In the two cultivars studied, ripening was associated with decrease of skin firmness, porosity, and relative humidity, and increase of Botrytis cinerea incidence. Chardonnay skins showed the highest $\mathrm{RH}$ and level of $V v P G 1$ expression, and lower disease incidence and penetrometry values. The observed difference between Pinot noir and Chardonnay confirmed the field's observations and could be used to better manage the harvest date.

Author Contributions: Conceptualization, L.G.-D. and L.M.; methodology, E.G., M.P. and S.L.; validation, L.G.-D.; investigation, M.A. and A.B.; writing-original draft preparation, M.A., S.L. and L.G.-D.; writing-review and editing, M.A., S.L. and L.G.-D.; supervision, L.G.-D.; project administration, D.C.; funding acquisition, L.M. and D.C. All authors have read and agreed to the published version of the manuscript. 
Funding: This research was funded by Moët Hennessy Champagne Service (MHCS).

Institutional Review Board Statement: Not applicable.

Informed Consent Statement: Not applicable.

Data Availability Statement: Not applicable.

Acknowledgments: We thank Sabrina Lacomme of the Bordeaux Imaging Center, member of the FranceBioImaging national infrastructure (ANR-10-INBS-04). We thank Baptiste Van Gysel, Chloé Cuif, Elise Moreel and Mélanie Bezruki for their technical support.

Conflicts of Interest: The authors declare no conflict of interest.

\section{References}

1. Ortega-Regules, A.; Ros-García, J.M.; Bautista-Ortín, A.B.; López-Roca, J.M.; Gómez-Plaza, E. Changes in skin cell wall composition during the maturation of four premium wine grape varieties. J. Sci. Food Agric. 2008, 88, 420-428. [CrossRef]

2. Fasoli, M.; Dell'Anna, R.; Dal Santo, S.; Balestrini, R.; Sanson, A.; Pezzotti, M.; Monti, F.; Zenoni, S. Pectins, Hemicelluloses and Celluloses Show Specific Dynamics in the Internal and External Surfaces of Grape Berry Skin during Ripening. Plant Cell Physiol. 2016, 57, 1332-1349. [CrossRef]

3. Van Kan, J.A.L. Licensed to kill: The lifestyle of a necrotrophic plant pathogen. Trends Plant Sci. 2006, 11, 247-253. [CrossRef] [PubMed]

4. Bocquet, F.; Moncomble, D.; Valade, M. Etat sanitaire de la vendange et qualité des vins. Le Vign. Champen. 1995, 7, 15-23.

5. Marchal, R.; Tabary, I.; Valade, M.; Moncomble, D.; Viaux, L.; Robillard, B.; Jeandet, P. Effects of Botrytis cinerea infection on champagne wine foaming properties. J. Sci. Food Agric. 2001, 81, 1371-1378. [CrossRef]

6. Deytieux-Belleau, C.; Geny, L.; Roudet, J.; Mayet, V.; Donèche, B.; Fermaud, M. Grape berry skin features related to ontogenic resistance to Botrytis cinerea. Eur. J. Plant Pathol. 2009, 125, 551-563. [CrossRef]

7. Fermaud, M.; Deytieux-Belleau, C.; Roudet, J.; L'hyvernay, A.; Darrieutort, G.; Daguisé, F.; Donèche, B.; Geny, L. Pourriture grise du vignoble. Des indicateurs de risque en développement. Union Girondine Vins Bordx. 2010, 1062, $25-29$.

8. Fermaud, M.; Deytieux-Belleau, C.; Roudet, J.; Darrieutort, G.; Geny, L. Water activity at the fruit surface: A potential indicator of grape berry susceptibility to Botrytis cinerea. Integr. Prot. Prod. Vitic. IOBC 2011, 67, 155-161.

9. Herzog, K.; Wind, R.; Töpfer, R. Impedance of the grape berry cuticle as a novel phenotypic trait to estimate resistance to Botrytis cinerea. Sensors 2015, 15, 12498-12512. [CrossRef] [PubMed]

10. Mlikota Gabler, F.; Smilanick, J.L.; Mansour, M.; Ramming, D.W.; Mackey, B.E. Correlations of Morphological, Anatomical, and Chemical Features of Grape Berries with Resistance to Botrytis cinerea. Phytopathology 2003, 93, 1263-1273. [CrossRef]

11. Sarig, P.; Zutkhi, Y.; Lisker, N.; Shkelerman, Y.; Ben-Arie, R. Natural and induced resistance of table grapes to bunch rots. Acta Hortic. 1998, 464, 65-70. [CrossRef]

12. Comménil, P.; Brunet, L.; Audran, J.C. The development of the grape berry cuticle in relation to susceptibility to bunch rot disease. J. Exp. Bot. 1997, 48, 1599-1607. [CrossRef]

13. Hill, G.; Stellwaag-Kittler, F.; Huth, G.; Schlosser, E. Resistance of Grapes in Different Developmental Stages to Botrytis cinerea. J. Phytopathol. 1981, 102, 328-338. [CrossRef]

14. Marois, J.J.; Nelson, J.K.; Morrison, J.C.; Lile, L.S.; Bledsoe, A.M. The Influence of Berry Contact within Grape Clusters on the Development of Botrytis cinerea and Epicuticular Wax. Am. J. Enol. Vitic. 1986, 37, 293-296.

15. Percival, D.C.; Sullivan, J.A.; Fisher, K.H. Effect of cluster exposure, berry contact and cultivar on cuticular membrane formation and occurrence of bunch rot (Botrytis cinerea PERS.: FR.) with 3 Vitis vinifera L. cultivars. Vitis 1993, 32, 87-97.

16. Paňitrur-De La Fuente, C.; Valdés-Gómez, H.; Roudet, J.; Acevedo-Opazo, C.; Verdugo-Vásquez, N.; Araya-Alman, M.; Lolas, M.; Moreno, Y.; Fermaud, M. Classification of winegrape cultivars in Chile and France according to their susceptibility to Botrytis cinerea related to fruit maturity. Aust. J. Grape Wine Res. 2018, 24, 145-157. [CrossRef]

17. Goetz, G.; Fkyerat, A.; Métais, N.; Kunz, M.; Tabacchi, R.; Pezet, R.; Pont, V. Resistance factors to grey mould in grape berries: Identification of some phenolics inhibitors of Botrytis cinerea stilbene oxidase. Phytochemistry 1999, 52, 759-767. [CrossRef]

18. Orlando, R.; Magro, P.; Rugini, E. Pectic enzymes as a selective pressure tool for in vitro recovery of strawberry plants with fungal disease resistance. Plant Cell Rep. 1997, 16, 272-276. [PubMed]

19. Kretschmer, M.; Kassemeyer, H.H.; Hahn, M. Age-dependent grey mould susceptibility and tissue-specific defence gene activation of grapevine berry skins after infection by Botrytis cinerea. J. Phytopathol. 2007, 155, 258-263. [CrossRef]

20. Brummell, D.A. Cell wall disassembly in ripening fruit. Funct. Plant Biol. 2006, 33, 103-119. [CrossRef] [PubMed]

21. Cantu, D.; Vicente, A.R.; Greve, L.C.; Dewey, F.M.; Bennett, A.B.; Labavitch, J.M.; Powell, A.L.T. The intersection between cell wall disassembly, ripening, and fruit susceptibility to Botrytis cinerea. Proc. Natl. Acad. Sci. USA 2008, 105, 859-864. [CrossRef] [PubMed]

22. Egea, J.; Romojaro, F.; Pretel, M.T.; Martinez-Madrid, M.C.; Costell, E.; Cascales, A. Application of sensory analysis to the determination of the optimum quality and harvesting moment in apricots. Acta Hortic. 2006, 701, 529-532. [CrossRef]

23. Geny, L.; Saucier, C.; Bracco, S.; Daviaud, F.; Glories, Y. Composition and Cellular Localization of Tannins in Grape Seeds during Maturation. J. Agric. Food Chem. 2003, 51, 8051-8054. [CrossRef] [PubMed] 
24. Saulnier, L.; Brillouet, J.-M.; Joseleau, J.-P. Structural studies of pectic substances from the pulp of grape berries. Carbohydr. Res. 1988, 182, 63-78. [CrossRef]

25. Robertson, G.L. The fractional extraction and quantitative determination of pectic substances in grapes and musts. Am. J. Enol. Vitic. 1979, 30, 182-186.

26. Apolinar-Valiente, R.; Romero-Cascales, I.; Williams, P.; Gómez-Plaza, E.; López-Roca, J.M.; Ros-García, J.M.; Doco, T. Effect of winemaking techniques on polysaccharide composition of Cabernet Sauvignon, Syrah and Monastrell red wines. Aust. J. Grape Wine Res. 2014, 20, 62-71. [CrossRef]

27. Guadalupe, Z.; Martínez-Pinilla, O.; Garrido, Á.; Carrillo, J.D.; Ayestarán, B. Quantitative determination of wine polysaccharides by gas chromatography-mass spectrometry (GC-MS) and size exclusion chromatography (SEC). Food Chem. 2012, 131, 367-374. [CrossRef]

28. Watrelot, A.A.; Le Bourvellec, C.; Imberty, A.; Renard, C.M.G.C. Interactions between Pectic Compounds and Procyanidins are Influenced by Methylation Degree and Chain Length. Biomacromolecules 2013, 14, 709-718. [CrossRef] [PubMed]

29. Reid, K.E.; Olsson, N.; Schlosser, J.; Peng, F.; Lund, S.T. An optimized grapevine RNA isolation procedure and statistical determination of reference genes for real-time RT-PCR during berry development. BMC Plant Biol. 2006, 6, 1-11. [CrossRef]

30. Lacampagne, S. Localisation et Caractérisation des Tannins Dans la Pellicule du Raisin: Etude de L'impact de L'organisation Physico-Chimique des Parois Cellulaires sur la Composante Tannique, la Qualité du Fruit et la Typicité des Raisins de Bordeaux. Ph.D. Thesis, Université de Bordeaux, Bordeaux, France, 2010. Available online: http://www.theses.fr (accessed on 31 December 2011).

31. Martínez, J.A.; Fernández-Trujillo, J.P. Necrotrophic fungi associated with epidermal microcracking caused by chilling injury in pickling cucumber fruit. Pesqui. Agropecu. Bras. 2007, 42, 593-598. [CrossRef]

32. Maury, C.; Madieta, E.; Le Moigne, M.; Mehinagic, E.; Siret, R.; Jourjon, F. Development of a mechanical texture test to evaluate the ripening process of cabernet franc grapes. J. Texture Stud. 2009, 40, 511-535. [CrossRef]

33. Deytieux, C.; Gény, L.; Donèche, B. Relation between hormonal balance and polygalacturonase activity in grape berry. Acta Hortic. 2005, 682, 163-170. [CrossRef]

34. Martins, V.; Garcia, A.; Alhinho, A.T.; Costa, P.; Lanceros-Méndez, S.; Costa, M.M.R.; Gerós, H. Vineyard calcium sprays induce changes in grape berry skin, firmness, cell wall composition and expression of cell wall-related genes. Plant Physiol. Biochem. 2020, 150, 49-55. [CrossRef]

35. Hardie, W.J.; O'Brien, T.P.; Jaudzems, V.G. Morphology, anatomy and development of the pericarp after anthesis in grape, Vitis vinifera L. Aust. J. Grape Wine Res. 1996, 2, 97-142. [CrossRef]

36. Brizzolara, S.; Minnocci, A.; Yembaturova, E.; Tonutti, P. Ultrastructural analysis of berry skin from four grapes varieties at harvest and in relation to postharvest dehydration. OENO One 2020, 54, 1021-1031. [CrossRef]

37. Battista, F.; Tomasi, D.; Porro, D.; Caicci, F.; Giacosa, S.; Rolle, L. Winegrape berry skin thickness determination: Comparison between histological observation and texture analysis determination. Ital. J. Food Sci. 2015, 27, 8-13. [CrossRef]

38. Rajaei, H. Changements cytochimiques et ultrastructuraux des parois cellulaires de la pellicule du raisin, Vitis vinifera, durant la croissance et la maturation de la baie. Can. J. Bot. 1987, 65, 1343-1355. [CrossRef]

39. Barnavon, L.; Doco, T.; Terrier, N.; Ageorges, A.; Romieu, C.; Pellerin, P. Analysis of cell wall neutral sugar composition, $\beta$-galactosidase activity and a related cDNA clone throughout the development of Vitis vinifera grape berries. Plant Physiol. Biochem. 2000, 38, 289-300. [CrossRef]

40. Barnavon, L.; Doco, T.; Terrier, N.; Ageorges, A.; Romieu, C.; Pellerin, P. Involvement of pectin methyl-esterase during the ripening of grape berries: Partial cDNA isolation, transcript expression and changes in the degree of methyl-esterification of cell wall pectins. Phytochemistry 2001, 58, 693-701. [CrossRef]

41. Rosli, H.G.; Civello, P.M.; Martínez, G.A. Changes in cell wall composition of three Fragaria $x$ ananassa cultivars with different softening rate during ripening. Plant Physiol. Biochem. 2004, 42, 823-831. [CrossRef]

42. Posé, S.; Kirby, A.R.; Mercado, J.A.; Morris, V.J.; Quesada, M.A. Structural characterization of cell wall pectin fractions in ripe strawberry fruits using AFM. Carbohydr. Polym. 2012, 88, 882-890. [CrossRef]

43. Jarvis, M.C. Plant cell walls: Supramolecular assemblies. Food Hydrocoll. 2011, 25, 257-262. [CrossRef]

44. Wu, H.C.; Bulgakov, V.P.; Jinn, T.L. Pectin methylesterases: Cell wall remodeling proteins are required for plant response to heat stress. Front. Plant Sci. 2018, 871, 1-21. [CrossRef]

45. Deytieux-Belleau, C.; Vallet, A.; Donèche, B.; Geny, L. Pectin methylesterase and polygalacturonase in the developing grape skin. Plant Physiol. Biochem. 2008, 46, 638-646. [CrossRef]

46. Nunan, K.J.; Davies, C.; Robinson, S.P.; Fincher, G.B. Expression patterns of cell wall-modifying enzymes during grape berry development. Planta 2001, 214, 257-264. [CrossRef]

47. Khan, N.; Fatima, F.; Haider, M.S.; Shazadee, H.; Liu, Z.; Zheng, T.; Fang, J. Genome-wide identification and expression profiling of the polygalacturonase (PG) and pectin methylesterase (PME) genes in grapevine (Vitis vinifera L.). Int. J. Mol. Sci. 2019, 20, 3180. [CrossRef]

48. Wang, J.; Mujumdar, A.S.; Deng, L.Z.; Gao, Z.J.; Xiao, H.W.; Raghavan, G.S.V. High-humidity hot air impingement blanching alters texture, cell-wall polysaccharides, water status and distribution of seedless grape. Carbohydr. Polym. 2018, 194, 9-17. [CrossRef]

49. Coombe, B.G.; McCarthy, M.G. Dynamics of grape berry growth and physiology of ripening. Aust. J. Grape Wine Res. 2000, 6, 131-135. [CrossRef] 
50. Goulao, L.F.; Oliveira, C.M. Cell wall modifications during fruit ripening: When a fruit is not the fruit. Food Sci. Technol. 2008, 19, 4-25. [CrossRef]

51. Mercado, J.A.; Matas, A.J.; Posé, S. Fruit and vegetable texture: Role of their cell walls. Encycl. Food Chem. 2018, 3, 1-7. [CrossRef]

52. Gapper, N.E.; McQuinn, R.P.; Giovannoni, J.J. Molecular and genetic regulation of fruit ripening. Plant Mol. Biol. 2013, 82, 575-591. [CrossRef] [PubMed]

53. Sénéchal, F.; Wattier, C.; Rustérucci, C.; Pelloux, J. Homogalacturonan-modifying enzymes: Structure, expression, and roles in plants. J. Exp. Bot. 2014, 65, 5125-5160. [CrossRef] [PubMed] 